\title{
TEACHER'S QUESTIONS USED IN TEACHING ENGLISH AT THE 1ST GRADE STUDENTS OF ONE JUNIOR HIGH SCHOOL IN BANDUNG
}

\author{
Gita Ernita $^{1}$, Tini Apriliani² \\ ${ }^{1}$ IKIP Siliwangi \\ ${ }^{2}$ IKIP Siliwangi \\ 1' gitaernita@gmail.com, ${ }^{2}$ tiniapriliani834@gmail.com
}

\begin{abstract}
Teachers are facilitators that assist students to make the learning process easier and more comfortale. Techer question is a part of learning process. The aim of this research is to find out the types of questions asked by teachers in teaching and learning process. This research is descriptive research. Participant of this research are two English teachers at SMP PGRI Bandung. The data collection used two instruments namely audio recording and note taking. From this research, researcher found that open ended questions are mostly occur in the classroom beside; yes/no questions, short answer questions, display questions, referential questions and non retrieval questions. During research, there are three kind of languages used by teachers, they are English, mixed English -Indonesian, and Indonesian.
\end{abstract}

Keywords: Teacher, Teacher Question, EFL Classroom

\section{INTRODUCTION}

A teacher plays very important roles in classroom. Harmer (2003) states four roles of teacher in teaching and learning process. Firstly, they have a role as a controller which mean that they have to determine what the student do, when they should speak, and what language form they have to use. Secondly, they are a director in the classroom. At this point, they are responsible to maintain students' engagement and motivation in order toflow smoothly and effectively.

To fulfill the teachers' role in the classroom, they need an appropriate language to build a good interactionwith the students. The interaction between the teachers and students in the classroom is called teacher talk. According to Nunan (2011), teacher talk is important for the organization and management of the classroom because through language that teacher'seither succeeded or fails in implementing their teaching plans. In terms of acquisition, teachertalk is important because it is probably the major source of comprehensibletarget language input the learner is likely to receive.

There are many parts of teacher talk. One of them is teacher question. Teacher question is the central point to be considered it will fulfill a good quality and enough input, output, and interaction. Kleinsasser, Richards, and Lockhart (2006) classify teacher question into three type's question: procedural question, convergent question, and divergent question. In EFL class, teacher questions are very important because it will lead the student to give the answer using English and create a quality interaction. The explanations above lead this study into investigate the teacher questions used by English teacher. 
Teacher questions are significant values for many instructional purposes: elicting student reflection and challenging deeper student understanding and engangement in the classroom (Adedoyin, 2011) Furthermore, Meng, Zhao, and Chattouphonexay (2012) define teacher questions as all types and structures of utterances clasified, either syntactically or functionally, as questions asked by teacher before, during, and after instruction in order to elicit students responses. In other research study, $\mathrm{Ma}$ (2014) classroom questioning is the skill of the elicitation method of teaching that is student oriented and advocated, gives an incentive to communicative activities.

From the above definitions, it can be concluded that teacher question is the skill for communicative activities in the classroom. The teacher usually asks to the student before, during and after the teaching in the class with the purposes to understand the materials.

Kim (2015) analyzes teacher question in four types: (1) open-ended questions (e.g., What should be included in a project to improve science in school environments?), (2) close-ended question (e.g., What is the formula for finding square area), (3)rhetorical question (e.g., are the conductor object that can delivered the heat well, aren'?), and (4) managerial question (e.g., will you turn to chapter 1?).Furthermore Kim (2015) in his research just focuses on two question types (1) open-ended question and (2) closed ended question. Moreover Kleinsasser, Richards, and Lockhart (2006), classify teacher question into three types question:proceduralquestion, convergent question, and divergent question.

\section{METHOD}

This study used qualitative method. This method was chosen to get the data.The respondent is students at seventh grade SMP PGRI 2 Bandung, theres is a teacher in the class as a participant. The teacher is perform in the class then the researcher observed what the teacher ask to the student.

In this classroom, there was 32 students consisted of 14 male and 18 female.Regarding the instrument, this study used observation. Observation sheet was used to investigated the teachers questions used in the classroom. Besides, types recorder was also used to get more accurate data.

After collect the data, then the researcher analyzed what teacher ask based on the teacher questions types.

\section{RESULTS AND DISCUSSION}

\section{Results}

The observation of one lesson during the lesson, the teacher taught about a descriptive text. From a short extract from the transcript showing the teacher's questioning about descriptive text and students' responses to the questions. The result of this study focus on the total question asked by the teacher in classroom during the English learning process. 
Table 1. Teacher's Questions

\section{Teaching stages}

Types of teach-er's questions
Total

Number $\%$

\begin{tabular}{lcc}
\hline Display/Closedquestion & 21 & 51 \\
\hline Referential/Open question & 20 & 49 \\
\hline Total Questions & 41 & 100
\end{tabular}

From the table, it can be seen that the appearance and closed questions dominate around $51 \%$ (21 questions) of 41 questions. On the other hand, references and open questions where the teacher does not answer and there is more than one answer that can be received have a total of 20 questions (49\%). The second session revealed almost the same as the first findings. The trial display and open questions are the types of questions that are often used by teachers. The total number of questions submitted by the teacher is 41 questions. Twenty-one questions are categorized as performances and closed questions. Twenty questions were categorized as referential questions and open questions. This escalation is influenced by the focus of procedural texts on signs and conceptual conjunctions (grammar).

Close question also belongs to display question Prihatanti (2010), for example closed question "what is the meaning ice cube in bahasa?" "what your aims for presenting this in the class?"

Table 2.Some different questions asked

\section{Closed Questions Open-Ended Question}

\begin{tabular}{|c|c|}
\hline what they want to delivered to you? & please tell me what they tell about? \\
\hline what they talking about? & $\begin{array}{l}\text { why they have idea to make hot chocolate } \\
\text { milk? }\end{array}$ \\
\hline Do understand my words? & why he didnt come to this class? \\
\hline what is the meaning goodest here? & $\begin{array}{l}\text { what your aims for presenting this in the } \\
\text { class? }\end{array}$ \\
\hline what is the meaning ice cube in bahasa? & How are you today? \\
\hline
\end{tabular}

Onwards, teachers pose a problem to the student who is one of the kinds of open questions, open problems Foong Pui Yee and Pui Yee (2002), in which the teacher asks the students to create their own questions based on a statement given. Opening of this pose, the teachers managed to lift a different answer from the students. Teachers also encourage students to analyze the error answer their classmates by asking, "Is it true?" So that students learn to investigate the truth of the answers. In addition, teachers develop students' communication skills and reasoning by asking, "Where?", "How?" And "Why?". 


\section{Discussion}

From the transcription analysis of the teaching and learning process, it was found that the authors found that teachers used referential open questions less than closed questions. students' way of thinking is much broader because the teacher's question serves to check the comparison of students. hereby the teacher hopes students will respond to the questions asked. teachers need to provide opportunities for students to express their ideas. The teacher said he used the commonly used questions which were categorized as display / closed questions. The purpose of this question is to measure students' understanding. The teacher gives assignments to students by grouping and asking them to present in front of the class with several questions asked by the teacher afterward. The teacher also asks students to translate into English. closed questions are usually used by the teacher to check questions and answers.

\section{CONCLUSION}

Based on the research, the writers conclud that when the teacher teaching in the classroon the teacher is always give the question type open-ended question and managerial question. The teacher is very communicative and student give good feedback when teacher ask some question in the class. The teacher have a technique for give the question in the best time for her students to get nore understanding the lesson and the teacher can cotroll the class so, the student not borring.

\section{ACKNOWLEDGMENTS}

We thank the family, parents, friends and lecturers who have given us support both morally and materially, so that we can complete and publish our journal.

\section{REFERENCES}

Adedoyin, O O. 2011. “The Impact of Teachers' in-Depth Pedagogical Mathematical Content Knowledge on Academic Performance: As Perceived by Botswana Junior Secondary School Pupils." European Journal of Educational Studies.

Foong Pui Yee, Author, and Foong Pui Yee. 2002. "Title The Role of Problems to Enhance Pedagogical Practices in the Singapore Mathematics Classroom The Role of Problems to Enhance Pedagogical Practices in the Singapore Mathematics Classroom." Source The Mathematics Educator.

Glisan, Eileen W., and Ruth Wajnryb. 2006. "Classroom Observation Tasks: A Resource Book for Language Teachers and Trainers." The Modern Language Journal.

Jeremy Harmer. 2003. "The Practice of English Language Teaching.” ELT Journal.

Kim, Sungho. 2015. "An Analysis of Teacher Question Types in Inquiry- Based Classroom and Traditional Classroom Settings." IOWA Research Online.

Kleinsasser, Robert C., Jack C. Richards, and Charles Lockhart. 2006. "Reflective Teaching in Second Language Classrooms." The Modern Language Journal.

Ma, Xiaoyan. 2014. "The Skills of Teacher's Questioning in English Classes." International Education Studies.

Meng, Junyi, Tao Zhao, and Athithouthay Chattouphonexay. 2012. "Teacher Questions in a Content-Based Classroom for EFL Young Learners." Theory and Practice in Language Studies.

Nunan, David. 2011. "Learner Strategy Training in the Classroom: An Action Research Study." In Methodology in Language Teaching, . 
Prihatanti, Nur Rohmah. 2010. "Hubungan Antara Tingkat Kecemasan Dengan Kejadian Dismenorea Pada Remaja Putri Di Pondok Pesantren Imam Syuhodo Polokorto Sukoharjo." Skripsi. 